\title{
Transformation of fen peat soils as the result of drainage and agricultural use in the Supraśl Dolna site, NE Poland
}

\author{
Aleksander Kiryluk ${ }^{1, *}$ \\ ${ }^{1}$ Białystok University of Technology, Faculty of Civil Engineering and Environmental Sciences, Department of Technology in \\ Environmental Engineering, 45E Wiejska Str, 15-351 Białystok, Poland \\ * Prof. Aleksander Kiryluk, DSc, PhD, Eng, a.kiryluk@pb.edu.pl, ORCID iD: https://orcid.org/0000-0001-7587-4851
}

Received: August 28, 2019

Accepted: April 1, 2020

Associated editor: A. Łachacz

\author{
Keywords \\ Agricultural management \\ Drained peatlan \\ Peatland degradation \\ Water table depth \\ Physical and water properties
}

\begin{abstract}
Peatlands occupy about $4 \%$ of Poland's area and perform important environmental and economic functions, including agricultural ones. In the last century, the majority of fen peatlands were drained for agricultural use. Drainage reduced the water retention of peat and initiated changes in their physical and water properties. In order to determine the rate and extent of changes in these properties, in the following years 1987, 2007 and 2018, studies were carried out within the Supraśl Dolna fen peatland, NE Poland, in two prognostic soil-moisture complexes: moist (PSMC-B) and dry (PSMC-C). Studies have shown that in the PSMC-B complex, the water table depth decreased to a maximum of $100 \mathrm{~cm}$ below ground level, while on the PSMC-C complex, the ground water decreased even to 150 $\mathrm{cm}$ below ground level. In the PSMC-B complex, peat mineralisation and physical-water properties changed to a small extent during the research period (statistically insignificant). In the PSMC-C habitat, the subsidence of peatland surface was observed $(11 \mathrm{~cm})$, bulk density increased, whereas the total porosity and full water capacity decreased. Deterioration in physical and water properties caused gradual degradation of drained fen peatland soils and their evolution towards organo-mineral soils. In order to slow down or even stop degradation processes in shallow and medium deep peat-mursh soils, there is a need to stop and regulate the outflow of water using efficient drainage facilities, as well as to carry out technical restoration works.
\end{abstract}

\section{Introduction}

There are approximately 49.6 thousand of peatlands in Poland, covering an area of almost 12 million ha (about $4 \%$ of the country) (Bieniek and Bieniek, 2007; Urban et al., 2019). Fen peatlands predominate (90\%), while other areas are covered by raised and transitional peatlands (Urban et al., 2019). Peatlands occur mainly in the northern part of Poland (so-called Lake District belt) and their number decreases towards the south. Large peatland complexes are located in the valleys of the rivers: Biebrza (approximately 100,000 ha), Noteć (50 000 ha), Tyśmienica and Krzna (30 000 ha), as well as in the Szczecin Lowland (25 000 ha) (Ilnicki, 2002). Research on drained fen peatlands was extensively conducted in the years 1960-1990 by the Institute of Technology and Life Sciences, Warsaw University of Life Sciences and Białystok University of Technology. The most multi-faceted studies were carried out at the Experimental Department of Institute of Technology and Life Sciences in the Kuwasy peatland, NE Poland (Okruszko, 1987).
After eliminating grazing and switching to a barn cattle farming, the use of fen peatlands decreased (Kiryluk, 2013). Currently, peatland research mainly concerns their environmental functions, including: greenhouse gas emissions (Holden, 2005; Joosten, 2009; Turbiak and Miatkowski, 2010; Jurczuk, 2012) and pollution of waters with nitrogen compounds from peat mineralization (Burzyńska, 2011; Frąckowiak, 1995). Research by Jurczuk (2012) shows that the amount of carbon dioxide emissions from drained peatlands is estimated at around 6.7 megaton (Mt), which is $3.1 \%$ of the carbon dioxide emission limit negotiated with the European Commission. Fen peatlands drainage was carried out in large areas in the $20^{\text {th }}$ century for their agricultural use. Irrigation systems on peatlands and their proper operation were not always installed along with drainage (Kaca, 2017; Kaca and Ostrowski 2014; Kiryluk, 2016). Peatland drainage stops the peat accumulation process and initiates the soil organic matter mineralization (Pawluczuk and Gotkiewicz 2003; Laiho, 2006). Lowering the water table depth and its proper regulation during the growing season are necessary for the rational agricultural 
use of peatlands (Kiryluk, 1999). Simultaneously with the loss of water in the peat soils, there are changes in the physical, water and chemical properties of peat (Gawlik, 1994; Łachacz, 2001; Prévost et al., 1999; Kalisz et al., 2015).

Due to the lack of subsoil irrigation and improper use, irreversible degradation processes occur a dozen or so years after drainage in a fen peatland. These processes clearly occurred on many drained peatlands in Poland (e.g. Piaścik and Gotkiewicz, 2004; Ilnicki and Szajdak, 2016; Glina et al., 2016; Grzywna, 2016) as well as in other countries (Bambalov, 2000; Laiho, 2006). The synthesis of research on changes in fen peatlands and their degradation, as well as concepts for their protection were described by Ilnicki and Szajdak (2016). An important, scientifically proven example of changes in the drained fen peatland in Poland is the Wizna site in the Narew valley (about 10,000 ha), which was drained and intensively used since 1960s without providing any adequate irrigation (Jankowska-Huflejt et al., 2013; Kołos and Próchnicki 2004; Szuniewicz et al., 1998).

Monitoring and stabilisation of peatland soils moisture is a basic activity for the proper functioning of these ecosystems (Holden, 2005; Kiryluk, 1999). After drainage of peatlands, changes occur in plant communities that reduce their species diversity (Kiryluk, 2007; Tomaszewska and Kołodziejczyk, 2010). As a result of peatland dehydration, its surface is shallower and smaller (Grzywna, 2016; Szuniewicz et al., 1998). It is estimated that at the current rate of organic matter loss, the surface of peat soils in Poland can be halved during next 100 years (Ilnicki, 2002). Study of Piaścik and Gotkiewicz (1995) showed that the transformation and evolution of fen peatland soils occurs according to the following scheme: peat soils $\rightarrow$ murshic-peat soils $\rightarrow$ mineral-murshic soils $\rightarrow$ semimurshic soils $\rightarrow$ postmurshic soils $\rightarrow$ mineral soils (Kabala et al., 2019). Currently in the world, and especially in Western Europe, actions are being taken to re-naturalise drained/degraded peatlands by increasing the habitat retention involving the retention of water within a catchment area and slowing its outflow (Joosten, 2000; Kiryluk, 2019; Wilson, 2008).

The aim of the study was to examine changes in physical and water properties of fen peatland soils within a drained meadow object, under conditions of decreasing rainfall during growing seasons and lack of irrigation during the 31-year period at the Supraśl Dolna site, NE Poland. Obtained results may be helpful in determining the amount of water retention in drained peatlands, which is of great importance in the presence of negative Climatic Water Balance (Łabędzki, 2006). The research is to justify that reduction of agricultural use of fen peatlands together with undertaking various restoration activities will restore their proper functionality in the natural environment.

\section{Study area and field works}

The research was carried out in the following years 1987, 2007 and 2018 within a drained fen peatlands of Supraśl Dolna site, adjacent to the Supraśl River near Białystok city, NE Poland. Study sites were established in two prognostic soil-moisture complexes, following classification of Okruszko (1988): 1) prognostic soil-moisture complex moist PSMC-B and 2) prognostic soil-moisture complex dry PSMC-C (Fig. 1). Profile 1 representing PSMC-B variant, is located approximately $200 \mathrm{~m}$ from the Supraśl riverbed. During the flow of large waters $\left(\mathrm{Q}_{3}\right)$, and during periodic floods, the PSMC-B area was subject to fluviogenic water supply. Currently, these processes do not occur due to the reduction of flows

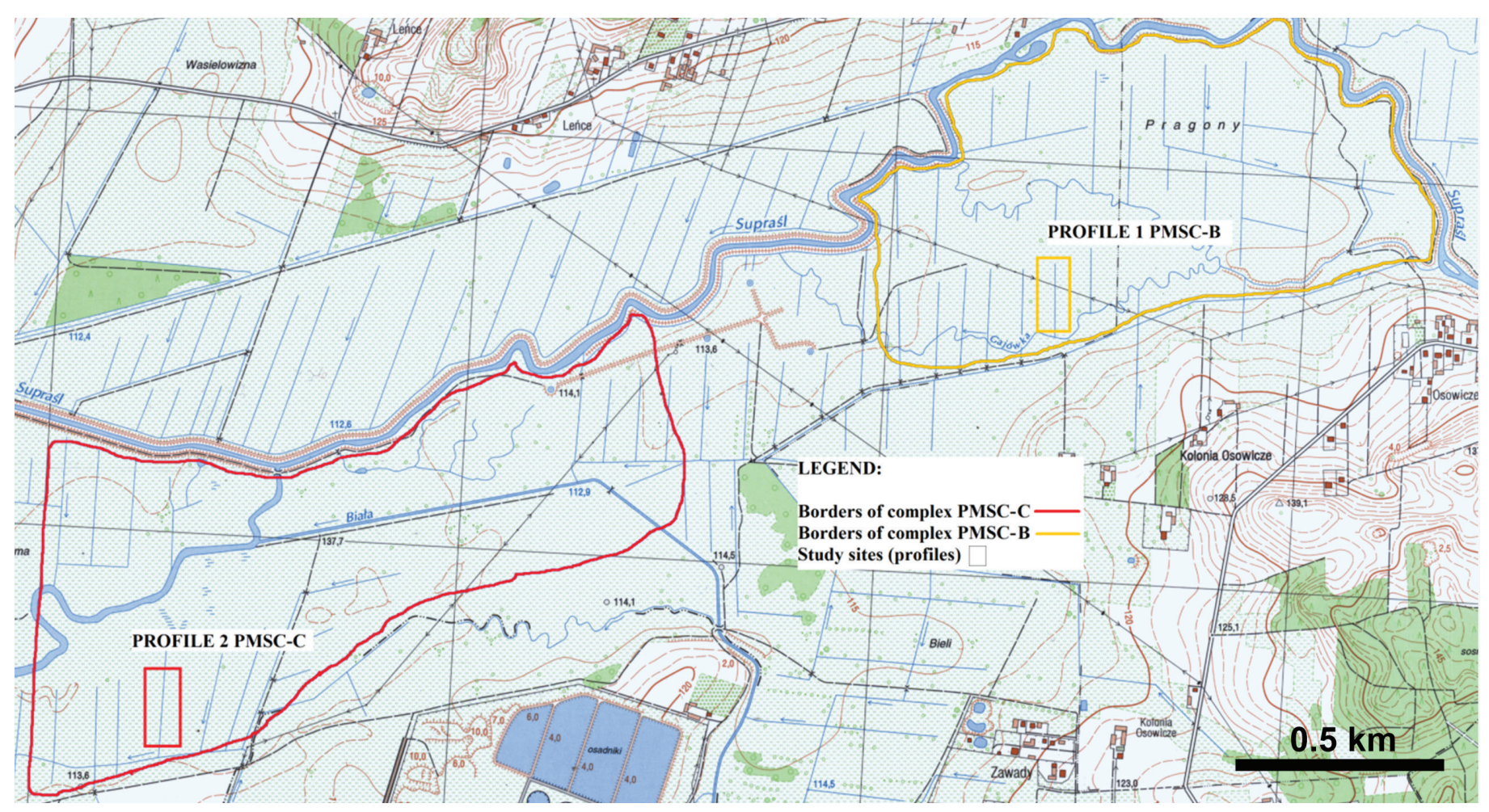

Fig. 1. Location map prepared based on GUGiK topographic map - Nowe Aleksandrowo (N3-4-107-c-4), scale 1:10000 (1999). 
Table 1. Description and classification of soil profiles (in 2018)

\begin{tabular}{|c|c|c|}
\hline Depth (cm) & Soil horizon & Soil material \\
\hline \multirow{2}{*}{\multicolumn{3}{|c|}{$\begin{array}{l}\text { Profile } 1 \text { - PSMC-B (prognostic soil-moisture complex: moist) } \\
\text { fibric murshic peat soil (PSC 2019) }\end{array}$}} \\
\hline & & \\
\hline \multicolumn{3}{|c|}{ Rheic Drainic Fibric Histosol (WRB 2015) } \\
\hline 0-17 & $\mathrm{M}$ & proper mursh $\left(\mathrm{Z}_{3}\right)$ \\
\hline $17-46$ & Oe & hemic reed peat \\
\hline $46-129$ & Oi & fibric reed peat \\
\hline $129+$ & G & sand \\
\hline \multirow{3}{*}{\multicolumn{3}{|c|}{$\begin{array}{l}\text { Profile } 2 \text { - PSMC-C (prognostic soil-moisture complex: dry) } \\
\text { fibric murshic peat soil (PSC 2019) } \\
\text { Rheic Drainic Fibric Histosol (WRB 2015) }\end{array}$}} \\
\hline & & \\
\hline & & \\
\hline $0-10$ & M & proper mursh $\left(\mathrm{Z}_{3}\right)$ \\
\hline $10-20$ & Oe & hemic reed peat \\
\hline $20-71$ & Oi & fibric reed peat \\
\hline $71+$ & G & sand \\
\hline
\end{tabular}

in the river. Actual moisture conditions in this habitat should be considered as optimal for the production of plant biomass. Mainly grasslands were created here: Alopecuretum pratensis, Phalaridetosum arundinaceae (Kiryluk, 2007). High moisture observed in the area of Profile 1 slows down the degradation processes, but makes it impossible to maintain cutting meadows and their proper economic use. Profile 2, representing PSMC-C variant, is located about $100 \mathrm{~m}$ from the Biała River (left bank tributary of the Supraśl River) in strongly drained area by open-ditch method. This area is not a subject to fluviogenic supply, what together with low amount of precipitation and absence of subsoil irrigation, caused deficiencies of soil water for plants. Under such conditions, soil degradation processes occur. Plant communities with a domination of Festuca rubra L. s. str., Cardaminopsis arenosa (L.) Hayek, Holcus lanatus L. with low agricultural usefulness appeared there.

Field survey included measurements of water table depth, description of soil morphology, soil sampling, peat subsidence measurements determined based on a terrain levelling, and degree of peat decomposition assessment. Soil samples were taken in 1987, 2007, and 2018. The soil classification in accordance with the Polish Soil Classification (2019) and the FAO-WRB (IUSS Working Group WRB, 2015) was used to describe soil profiles. The water table depth was measured in installed piezometers from April to September in each of the study years. Piezometers were made of perforated PVC pipes $15 \mathrm{~cm}$ in diameter. Each piezometer was installed through the organic material and have reached the underlying mineral layer (sand). Peat decomposition was assessed in the field using the von Post (1922) scale. Some stabilised piezometers were used to measure the peatland subsidence. Undisturbed soil samples were taken from the soil profiles in 4 replicates to $100 \mathrm{~cm}^{3}$ metal cylinders from 5-10, 25-30, 55-60 and 95-100 cm depths (Profile 1) and from 5-10, 25-30, 55-60 and 75-80 depths (Profile 2) in order to determine full water capacity. Parallel soil samples were collected in plastic bags and used for ash content determination.

\section{Laboratory analysis}

Ash content was determined by the dry combustion method using a muffle furnace at $550^{\circ} \mathrm{C}$ (Sapek and Sapek, 1997). Particle density was calculated using Zawadzki's formula $\mathrm{W}=0.011 \mathrm{~A}+$ 1.451, where: $\mathrm{W}$ - specific density, A - ash content and 1.451 constant specific density for soil humus (Okruszko, 1971). The bulk density of dry soil was calculated using the formula $\mathrm{O}=0.004 \mathrm{~A}+$ 0.0913, where: O - bulk density, A - ash content, and 0.0913 constant bulk density for soil humus (Okruszko, 1971). Total porosity was calculated based on particle and bulk density according to Okruszko (1971) formula. Full water capacity was determined by gradual, full saturation (to constant weight) of soil samples completely flooded with water (Okruszko, 1971).

Statistical analysis of the significance of changes in physical and water properties of the studied soils was performed using ANOVA analysis of variance (Statistica 13.1). It consisted of determining the least significant differences (LSD).

\section{Results and discussion}

\subsection{Morphology of studied soils}

The soil in Profile 1 (Fig. 1) was subjected to fluviogenic processes occurring at least 2 times a year. Currently, these processes do not occur with such intensity as in the past due to the reduction of flows in the river. However, despite the lack of water outflows, the soil moisture is high. This is caused by the local depression of the terrain, as well as the presence of water in several oxbow lakes, visible on the map (Fig. 1). This soil was classified as deep organic soils (Ilnicki, 2002).

Profile 2 was located in the upper part of the object (Fig. 1), on which a regular drainage ditch network draining water to the Biała River was constructed. This area was again drained in the 1980s. One of the effects of intensive drainage of this area was the appearance of stinging nettle (Urtica dioica L.) communities as the effect of peat mineralization, which was an indirect indicator of high nitrogen amounts in soil (Fodor and Cseh, 1993; Kiryluk, 2007). This soil was classified as medium deep organic soil (Ilnicki, 2002).

\subsection{Water table depth within study sites}

The water table depth within drained peatland varied significantly throughout the year. The largest decrease in ground water level occurred between May and September in the PSMC-C site.

In the PSMC-B complex, the ground water table depth was shaped in the years 1987 and 2007 by floods from the Supraśl River. While in later years, mainly by precipitation and a single irrigation carried out after harvesting the first grass swath. Studies have shown that water did not decrease $100 \mathrm{~cm}$ below ground level throughout the growing season in the moist complex (PSMC-B). High amplitude of ground water table depth after drainage of fen peatlands in Poland was also indicated by Frąckowiak (1995), Gawlik (1994), and Piaścik and Gotkiewicz (2004). 


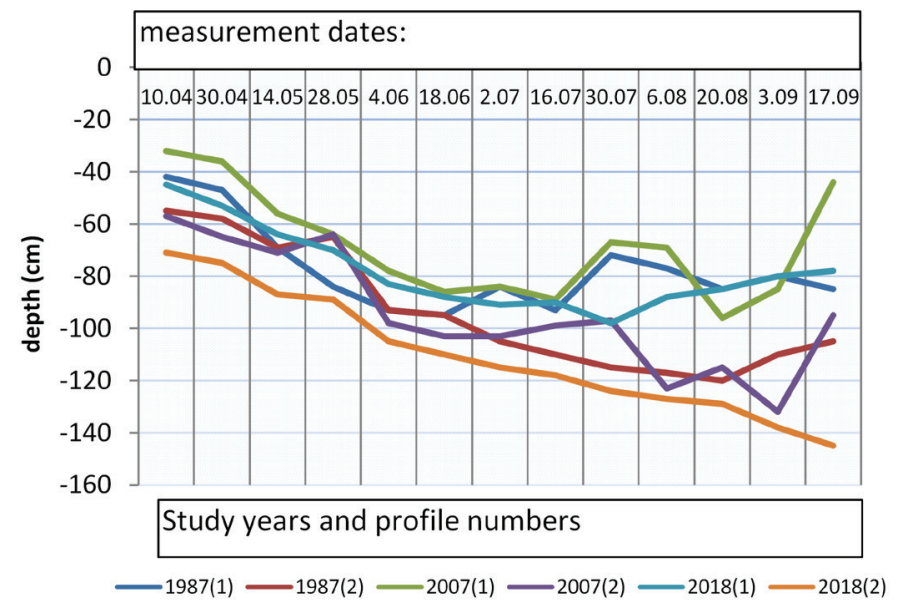

Fig. 2. Ground water table depth (cm) within study sites - (1) and (2) - in 1987, 2007, and 2018.

In the PSMC-C dry complex, the ground water table depth was mainly shaped by atmospheric precipitation and sporadic subsoil irrigation. Fluviogenic processes did not occur in this habitat. In 2018, the ground water table decreased to a depth of $150 \mathrm{~cm}$, which was, among others, a result of soil and hydrological drought occurring in Podlasie region (website 1, website 2).

The height of the capillary rise from ground water table depended on the degree of peat decomposition in the soil profile and its thickness (Łabędzki, 1995). Changes in ground water table depths in the long term influenced the formation of phytocoenoses, both hygrophytic and segetal, as stated by the present author in other studies at this site (Kiryluk, 1999; Kiryluk, 2007).

\subsection{Changes in physical and water properties of soils}

On the PSMC-B complex in the period 1987-2018, an increase in bulk density by $0.027 \mathrm{~g} \cdot \mathrm{cm}^{-3}$ was found in the mursh (M) horizon (Table 2). The total porosity decreased by $3.8 \%$ by volume, as well as the full water capacity decreased by $3.2 \%$ by volume. In the Oe horizon, changes in physical properties and water capacity were small in the study period. In the Oi horizon, there was a slight increase in bulk density, probably due to the increase in the content of mineral parts, penetrating as a result of fluviogenic processes into the deeper layers of the profile. Small changes in the physical and water properties in that profile resulted from the optimal moisture content and persistence of the ground water table at a depth of not more than $85 \mathrm{~cm}$ (Fig. 2). Thickness measurement readings showed that in the years 1987-2018 in these conditions, the peatland was lowered by $2 \mathrm{~cm}$ (Table 3 ). This is a very slight decrease and not statistically significant.

On the PMSC-C complex (Profile 2), changes were found at each of the three soil horizons. The biggest changes occurred at the mursh (M) horizon (Table 2). During the 31-year study, the bulk density increased in that horizon by $0.094 \mathrm{~g} \cdot \mathrm{cm}^{-3}$, the total porosity decreased by $4.2 \%$ by volume. Significant peatland subsidence was found in this complex. Measurements showed that the peatland surface lowering was $11 \mathrm{~cm}$. The average annual subsidence was $0.36 \mathrm{~cm} \cdot \mathrm{year}^{-1}$. In comparison to other drained objects (Szuniewicz et al., 1998; Oleszczuk et al., 2008; Glina et al., 2019), the subsidence is much smaller and this may be due to the meadow use of this peatland, ensuring the covering of the surface with grass vegetation. Studies on the Kuwasy peatland, NE Poland, showed that the average subsidence rate of peat soils in the years 1958-1982 was $1.34 \mathrm{~cm} \cdot \mathrm{year}^{-1}$. Research on peatlands in NW Germany showed that within 50 years, the peatland subsidence occurred at a rate of $1.7 \mathrm{~cm} \cdot \mathrm{year}^{-1}$ (Günther, 2013). Peat subsid-

Table 2. Physical and water properties of study soils in the years 1987, 2007 and 2018

\begin{tabular}{|c|c|c|c|c|c|c|c|c|c|c|}
\hline \multirow[b]{3}{*}{ Properties } & \multirow{3}{*}{$\begin{array}{l}\text { Profile } \\
\text { number }\end{array}$} & \multicolumn{9}{|c|}{ Soil horizon } \\
\hline & & \multicolumn{3}{|c|}{ Mursh - M } & \multicolumn{3}{|c|}{ Hemic reed peat - Oe } & \multicolumn{3}{|c|}{ Fibric reed peat - Oi } \\
\hline & & 1987 & 2007 & 2018 & 1987 & 2007 & 2018 & 1987 & 2007 & 2018 \\
\hline \multirow[t]{2}{*}{ Thickness (cm) } & 1 & 16 & 17 & 17 & 31 & 30 & 29 & 84 & 83 & 83 \\
\hline & 2 & 12 & 11 & 10 & 15 & 12 & 10 & 55 & 54 & 51 \\
\hline \multirow[t]{2}{*}{ Bulk density $\left(\mathrm{g} \cdot \mathrm{cm}^{-3}\right)$} & 1 & 0.256 & 0.268 & 0.283 & 0.244 & 0.251 & 0.276 & 0.165 & 0.164 & 0.164 \\
\hline & 2 & 0.311 & 0.398 & 0.405 & 0.276 & 0.283 & 0.290 & 0.165 & 0.173 & 0.176 \\
\hline \multirow[t]{2}{*}{ Full water capacity (\% vol.) } & 1 & 83.7 & 82.5 & 80.5 & 8.6 & 87.5 & 87.1 & 89.4 & 88.7 & 89.0 \\
\hline & 2 & 81.7 & 80.1 & 78.3 & 83.5 & 83.0 & 82.9 & 87.7 & 88.1 & 88.0 \\
\hline \multirow[t]{2}{*}{ Total porosity (\% vol.) } & 1 & 85.1 & 85.6 & 81.3 & 84.2 & 88.8 & 88.6 & 91.4 & 91.0 & 91.3 \\
\hline & 2 & 83.2 & 85.6 & 79.0 & 84.7 & 84.6 & 83.2 & 89.5 & 89.2 & 89.0 \\
\hline \multirow[t]{2}{*}{ Ash content (\% d.m.) } & 1 & 16.3 & 16.6 & 16.8 & 14.5 & 14.7 & 14.6 & 12.3 & 12.5 & 12.4 \\
\hline & 2 & 17.2 & 17.3 & 17.5 & 15.2 & 15.5 & 15.7 & 11.8 & 11.7 & 12.3 \\
\hline \multirow[t]{2}{*}{ Degree of peat decomposition* } & 1 & - & - & - & $\mathrm{H} 4$ & $\mathrm{H} 4$ & $\mathrm{H} 4$ & H3 & H3 & H3 \\
\hline & 2 & - & - & - & $\mathrm{H} 4$ & H4 & $\mathrm{H} 4$ & H3 & H3 & H3 \\
\hline
\end{tabular}

* according to the von Post scale 
ence in most cases is an irreversible process, which together with intensive organic matter mineralization may lead to disappearance of shallow peatlands (Jurczuk, 2012). The abundant presence of water in weakly disturbed peat soils minimizes organic matter mineralization and further degradation processes (Joosten, 2000). Each drainage of peatlands causes their subsidence, changes in the physical and water properties of peat and decrease in their retention capacity. Such clear changes were found in long-term study of the Wizna peatland (Jurczuk, 2000; Okruszko, 1987), in central Poland (Glina et al., 2016), in Eastern European countries (Bambalov, 2000), as well as in Finland (Kaakinen and Salminen, 2008). As a result of changes in physical properties, the full water capacity (which corresponds to the water retention capacity in the soil root layer) decreased by $3.4 \%$ by volume. The retention capacity of peat-mursh soil is mainly due to the high porosity of peat.

Degree of peat decomposition in both studied profiles based on the von Post scale ranged from $\mathrm{H} 3$ (fibric peat) to $\mathrm{H} 4$ (hemic peat) and decreased with depth (Table 2). The ash content in studied peat soils should be considered as medium (Okruszko, 1994). The most mineral material occurred in the mursh (M) horizons, what could have been caused by fluviogenic processes, as well as increased mineralization of organic matter. In deep soil profile 1 , ash content was $12.4-16.8 \%$, whereas in profile 2 it ranged from 11.6 to $17.5 \%$.

Comparison of soil profiles in moist and dry habitat indicates that the main factor in the increase in peat mass compaction, and thus the reduction in total porosity and full water capacity, was the reduction of soil moisture, as the effect of of ground water level depth lowering. There was no intensive meadow and pasture management on the study sites and there was no rational water management. The most important problem in the dry habitat (Profile 2) is the lack of subsoil irrigation during periods of negative water balance (WCB). The lack of systematic irrigation also results from the de-capitalisation and non-functionality of drainage facilities (Kiryluk, 2016). This results in multidirectional degradation processes of organic soils, as evidenced by results of the present author's long-term observation and research in the Supraśl River valley (Kiryluk, 2016). Inproper use of fen peatland meadows causes their further drying, intensification of the murshing processes and changes in phytocoenoses towards their synatropisation (Kiryluk, 2013). The utility value of peatlands and their environmental functions are also undergoing unfavourable changes. Extensively used meadows, still remain the main type of low peatlands management in Poland, especially those in the river valleys (Jurczuk, 2000; Kiryluk, 2007; Kiryluk, 2013; Glina et al., 2016, 2019).The lack of sustainable management on fen peatlands is one of the reasons for their degradation, what indicates the need for research and implementation of practical solutions in such areas.

In relation to 1987 (the beginning of the study), the significance of differences in 2007 and 2018 was compared. In profile 1 (Table 3), there were no statistically significant differences $(<0.05)$ in bulk density of soil materials at all four tested depths. There were also no significant differences in the total porosity across that profile. Similarly, there were no significant differences in ash content. However, statistically significant differences were found in full water capacity: at a depth of 5-10 cm between 1987 and
Table 3. The significance of LSD differences estimated with the Tukey test

\begin{tabular}{|c|c|c|c|c|c|c|}
\hline $\begin{array}{l}\text { Depth } \\
\text { (cm) }\end{array}$ & $\begin{array}{l}\text { Profile } \\
\text { No. }\end{array}$ & Years & $\begin{array}{l}\text { Bulk } \\
\text { density }\end{array}$ & $\begin{array}{l}\text { Total } \\
\text { porosity }\end{array}$ & $\begin{array}{l}\text { Full water } \\
\text { capacity }\end{array}$ & $\begin{array}{l}\text { Ash } \\
\text { content }\end{array}$ \\
\hline \multirow[t]{4}{*}{$5-10$} & 1 & 2007 & 0.99 & 0.99 & 0.17 & 0.86 \\
\hline & & 2018 & 0.99 & 0.99 & $0.01 *$ & 1.00 \\
\hline & 2 & 2007 & $0.01 *$ & $0.01 *$ & $0.01 *$ & 1.00 \\
\hline & & 2018 & $0.01^{*}$ & $0.01^{*}$ & $0.01 *$ & 1.00 \\
\hline \multirow[t]{4}{*}{$25-30$} & 1 & 2007 & 0.99 & 0.99 & $0.01 *$ & 0.95 \\
\hline & & 2018 & 0.99 & 0.99 & $0.01 *$ & 1.00 \\
\hline & 2 & 2007 & 0.27 & 1.00 & 0.02 & 1.00 \\
\hline & & 2018 & 0.89 & 0.27 & 0.19 & 1.00 \\
\hline \multirow[t]{4}{*}{$55-60$} & 1 & 2007 & 0.99 & 0.99 & 0.43 & 1.00 \\
\hline & & 2018 & 0.99 & 0.99 & 1.00 & 1.00 \\
\hline & 2 & 2007 & 0.54 & 1.00 & 0.45 & 1.00 \\
\hline & & 2018 & 0.18 & 1.00 & 0.65 & 1.00 \\
\hline \multirow[t]{2}{*}{ 95-100 } & 1 & 2007 & 0.99 & 0.48 & 0.88 & 0.97 \\
\hline & & 2018 & 0.99 & 0.50 & $0.01^{*}$ & 1.00 \\
\hline \multirow[t]{2}{*}{$75-80$} & 2 & 2007 & 0.96 & 0.34 & 0.33 & 0.76 \\
\hline & & 2018 & 0.96 & 0.21 & 1.00 & 0.72 \\
\hline
\end{tabular}

* Statistically significant result at $\alpha=0.05$

2018, at a depth of 25-30 cm between 1987 and 2007 and 2018, and at a depth of 95-100 cm between 1987 and 2018 (Table 3).

In profile 2 , there were more statistically proven differences of the studied properties between studied years (Table 3). Bulk density changed in the mursh horizon between 1978, 2017 and 2018. Also, statistically proven differences in total porosity in 2007 and 2018 in the mursh horizon were found. Larger statistically significant differences in the full water capacity in profile 2 occurred at depth of 5-10 cm for all studied years and at a depth of 25-30 cm between 1987 and 2007.

Modern research should aim at developing the effective technical solutions that will inhibit and minimize peatland degradation processes, as well as the restoration of degraded peatlands. In Western Europe, active protection and reclamation of lowland fen peatland is carried out, among others, through strong hydration of peatlands (so-called re-swamping), removal of hydrophobic mursh, removal of segetal vegetation, as well as the introduction of new desirable plant species in order to reduce evaporation from peatlands lacking a dense plant cover (Quinty and Rochefort, 2003; Klimkowska, 2006; Schumann and Joosten, 2008).

\section{Conclusions}

(1) In the moist soil complex (PSMC-B, profile 1), the ground water table depth was characterized by low dynamics during the growing season. The water table depth more than $100 \mathrm{~cm}$ below ground level was not observed during growing season.

(2) In the dry soil complex (PSMC-C, profile 2) the lowering of ground water table depth even to $150 \mathrm{~cm}$ below ground level was observed during growing season. 
(3) The availability of water for plants on the PSMC-B complex slowed down the peat degradation process. The soil bulk density, total porosity and full water capacity slightly changed over a period of 31 years.

(4) Increase in bulk density, decrease of total porosity and full water capacity in the PSMC-C soil, might confirm advanced mursh forming process. These changes were mainly caused by low soil hydration and high dynamics of the water level during the growing season.

(5) If one compare the first and the last year of the study, the subsidence of the studied peatlands was $2 \mathrm{~cm}$ (PSMC-B) and $11 \mathrm{~cm}$ (PSMC-C).

\section{References}

Bambalov, N., 2000. Organic substance and classification of the meliorated soils forming as a results of peat layer destruction. Acta Agrophysica 26, 109-119.

Bieniek, A., Bieniek, B., 2007. Subsidence of the surface of extensively utilized muck soils in the „Siódmak” peatland. Inżynieria Ekologiczna 18, 22-24. (in Polish).

Burzyńska, I., 2011. Ocena związku między zawartością rozpuszczalnego węgla organicznego $\mathrm{w}$ glebie a stężeniem mineralnych form azotu w płytkich wodach gruntowych z zagrody i jej otoczenia. Ochrona Środowiska i Zasobów Naturalnych 48, 432-438.

Fodor, F., Cseh, E., 1993. Effect of different nitrogen forms and iron chelates on the development of stinging nettle, Journal of Plant Nutrition 16(11), 2239-2253, https://doi.org/10.1080/01904169309364683

Frąckowiak, H., 1995. Wpływ głębokości odwodnienia gleb organicznych użytkowanych łąkowo na przebieg mineralizacji azotu i masy organicznej. In: Torfoznawstwo w badaniach naukowych i praktyce. Materiały Seminaryjne IMUZ 34, 185-190.

Gawlik, J., 1994. Wpływ głębokiego i długotrwałego odwodnienia gleb hydrogenicznych na ich fizyczno-wodne właściwości. Wiadomości IMUZ 18(2), 9-28.

Glina, B., Gajewski, P., Kaczmarek, Z., Owczarzak, W., Rybczyński, P., 2016. Current state of peatland soils as an effect of long-term drainage preliminary results of peatland ecosystems investigations in the Grójecka Valley (central Poland). Soil Science Annual 67(1), 3-9. https:// doi.org/10.1515/ssa-2016-0001

Glina, B., Gajewski, P., Mendyk, Ł., Zawieja, B., Kaczmarek Z., 2019. Recent changes in soil properties and carbon stock in fen peatlands adjacent to open-pit lignite mines. Land Degradation and Development, 30(18), 2371-2380. https://doi.org/10.1002/ldr.3428

Grzywna, A., 2016. Zanikanie powierzchni torfowiska na odwodnionych użytkach zielonych Polesia. Acta Scientiarum Polonorum Formatio Circumiectus 15 (1), 81-89. DOI: http://dx.doi.org/10.15576/ASP. FC/2016.15.1.81www.formatiocircumiectus.actapol.net/pl

Günther, J., 2013. Das Moor-und Fehnmuseum Elisabethfehn im Landkrteis Cloppenburg nach seiner Umgestaltung und Neuausrichtung. Telma 43, 199-154.

Holden, J., 2005. Peatland hydrology and carbon cycling: why small-scale process matters. Philosophical Transactions of the Royal Society A 363, 2891-2913.

Ilnicki, P., 2002. Torf i torfowiska. Wydawnictwo Akademii Rolniczej w Poznaniu, Poznań: 606 pp.

Ilnicki, P., Szajdak L.W., 2016. Zanikanie torfowisk, Poznań, 312 pp.

IUSS Working Group WRB, 2015. World reference base for soil resources 2014, update 2015. International Soil Classification System for Naming Soil and Creating Legends for Soil Maps. Food and Agriculture Organization of the United Nations, Rome, 190 pp.
Jankowska-Huflejt, H., Prokopowicz, J., Lipiński, J., 2013. Gospodarcze i ekologiczne skutki melioracji torfowisk w otoczeniu mineralnych gleb gruntów ornych o różnej jakości (na przykładzie doliny rzeki Por i torfowiska Kuwasy). Woda-Środowisko-Obszary Wiejskie 13, 2(42), 33-52.

Joosten, H., 2000. Peatland conservation in central and southern Europe. In: Rochefort, L. and Daigle, J.Y. (eds.), Sustaining our peatlands. Proceding. $11^{\text {th }}$ Int. Peat Congress, Quebec City, Canada, August 6-12, 2000, 2, 1044-1049.

Joosten, H., 2009. The Global Peatland CO2 Picture. Peatland status and emissions in all countries of the world. Produced for the UN-FCCC meetings in Bangkok, September/October 2009. Wetlands International, $35 \mathrm{pp}$.

Jurczuk, S., 2000. Wpływ regulacji stosunków wodnych na osiadanie i mineralizację gleb organicznych. Biblioteczka Wiadomości IMUZ 96: $116 \mathrm{pp}$

JurczukS., 2012.Emisja dwutlenku węgla ze zmeliorowanych gleb organicznych w Polsce Woda-Środowisko-Obszary Wiejskie 12(39), 63-76.

Kaakinen E., Salminen P., 2008. Mire conservation in Finland. In: Finland - fenland. Research and sustainable utilization of mires and peat. R. Korhonen, L. Korpela, S. Sarkkola (eds). Maahenki Ltd. Finnish Pealtand Society: 112-121.

Kabała, C., Charzyński, P., Chodorowski, J., Drewnik, M., Glina, B., Greinert, A., Hulisz, P., Jankowski, M., Jonczak, J., Łabaz, B., Łachacz, A., Marzec, M., Mendyk, Ł., Musiał, P., Musielok, Ł., Smreczak, B., Sowiński, P., Świtoniak, M., Uzarowicz, Ł., Waroszewski, J., 2019. Polish Soil Classification, 6th edition - principles, classification scheme and correlations. Soil Science Annual 70(2), 71-97. https://doi.org/10.2478/ ssa-2019-0009

Kaca, E., 2017. Methodology of assessing the relative environmental validity of developing drainage and irrigation on a regional scale. Journal of Water and Land Development 35, 101-112. DOI: 10.1515/jwld2017-0073.

Kaca, E., Ostrowski, J., 2014. Uwarunkowania i zasadność rozwoju melioracji. W: Uwarunkowania rozwoju melioracji wodnych w Polsce. Red. E. Kaca. Woda-Środowisko-Obszary Wiejskie. Rozprawy naukowe i monografie 37, 167-191.

Kaakinen, E., Salminen, P., 2008. In: Korhonen, et al. (Eds.), Mire Conservation in Finland, pp. 112-121.

Kalisz, B., Łachacz, A., Głażewski, R., 2015. Effects of peat drainage on labile organic carbon and water repellency in NE Poland. Turkish Journal of Agriculture and Forestry 39(1), 20-27.

Kiryluk, A., 1999. Wody gruntowe na zmeliorowanym torfowisku niskim i ich wpływ na biocenozę łąkową. Roczniki AR w Poznaniu, Melioracje i Inżynieria Środowiska, nr 20, cz. 1, 245-255.

Kiryluk, A. 2007. Zmiany siedlisk pobagiennych i fitocenoz w dolinie Supraśli. Woda-Środowisko-Obszary Wiejskie, Rozprawy naukowe i monografie $\mathrm{nr} 20,148 \mathrm{pp}$.

Kiryluk, A., 2013. Retardacja przekształcania warunków siedliskowych torfowiska niskiego w dolinie rzeki Supraśli w latach 1987-2011. Inżynieria Ekologiczna 34, 158-165.

Kiryluk, A., 2016. Ocena stanu technicznego i funkcji środowiskowych urządzeń melioracyjnych na obiekcie Supraśl Dolna. Inżynieria Ekologiczna 46, 38-46.

Kiryluk, A., 2019. The influence of drainage devices and post-bog soil changes on water retention in drained ower Supraśl River. Journal of Ecological Engineering 20(8), 120-128. DOI .org/10.12911/22998993/110788.

Klimkowska, A., 2006. Rola glebowego banku nasion w renaturyzacji torfowisk na przykładzie Bagna Całowanie. Woda-Środowisko-Obszary Wiejskie 6.1(16), 183-194.

Kołos, A., Próchnicki, P., 2004. Zastosowanie retrospektywnej analizy zdjęć lotniczych w projektowaniu zabiegów renaturalizacyjnych na torfowisku Wizna (Dolina Narwi). Teledetekcja Środowiska 33, 36-44. 
Laiho, R., 2006. Decomposition in peatlands: Reconciling seemingly contrasting results on the impacts of lowered water levels. Soil Biology and Biochemistry 38(8), 2011-2024. https://doi.org/10.1016/j.soilbio.2006.02.017

Łabędzki, L., 1995. Ocena właściwości podsiąkowych gleb pobagiennych. W: Torfoznawstwo w badaniach naukowych i praktyce. Materiały Seminaryjne IMUZ 34, 268-272.

Łabędzki L., 2006. Susze rolnicze - zarys problematyki oraz metodyka monitorowania i klasyfikacji. Woda-Środowisko-Obszary Wiejskie, Rozprawy Naukowe i Monografie 7, 107 pp.

Łachacz, A., 2001. Geneza i właściwości płytkich gleb organogenicznych na sandrze mazursko-kurpiowskim. Rozprawy i Monografie UWM w Olsztynie, 49, $119 \mathrm{pp}$.

Okruszko, H., 1971. Określenie ciężaru właściwego gleb hydrogenicznych na podstawie zawartości w nich części mineralnych. Wiadomości IMUZ 10(1), 47-54.

Okruszko, H.,1987. Synteza wyników 25-letniego doświadczenia nad porównaniem sposobów użytkowania gleby torfowej w Zakładzie Doświadczalnym Biebrza. Biblioteczka Wiadomości IMUZ 68, 225241.

Okruszko, H., 1988. Zasady podziału gleb hydrogenicznych na rodzaje oraz łączenie rodzajów w kompleksy. Roczniki Gleboznawcze - Soil Science Annual 39(1), 127-152.

Okruszko, H., 1994. System of hydrogenic soil classification used in Poland. In.: Taxonomy of hydrogenic soils and sites used in Poland. Red. H. Okruszko. Biblioteczka Wiadomości IMUZ 84, 5-27.

Oleszczuk, R., Regina, K., Szajdak, L., Höper, H., Maryganova, V., 2008. Impacts of agricultural utilization of peat soils on the greenhouse gas balance. In Strack, M. (ed), Peatlands and Climate Change (70-97), International Peatland Society, Finland.

Pawluczuk, J., Gotkiewicz, J., 2003. Ocena procesu mineralizacji w glebach wybranych ekosystemów torfowiskowych Polski Północno-Wschodniej w aspekcie ochrony zasobów glebowych. Acta Agrophysica 1(4), 721-728.

Piaścik, H., Gotkiewicz, J., 1995. Procesy degradacji na odwodnionych torfowiskach terenów młodoglacjalnych. Zeszyty Problemowe Postępów Nauk Rolniczych 418, 185-190.
Piaścik, H., Gotkiewicz, J., 2004. Przeobrażenia odwodnionych gleb torfowych, jako przyczyna ich degradacji. Roczniki Gleboznawcze - Soil Science Annual 55(2), 331-338.

Polish Soil Classification (Systematyka gleb Polski), wyd. 6, 2019. Wydawnictwo Uniwersytetu Przyrodniczego we Wrocławiu, Polskie Towarzystwo Gleboznawcze, Wrocław-Warszawa. 292 pp.

Prévost, M., Plamondon, A. P., Belleau, P., 1999. Effects of drainage of a forested peatland on Water quality and quantity. Journal of Hydrology $214,130-143$.

Quinty, F, Rochefort, L., 2003. Peatland restoration guide, $2^{\text {nd }}$ ed. Canadian Sphagnum Peat Moss Association, New Brunswick Department of Natural Resources and Energy, Quebec, Canada. 107 pp.

Sapek, A., Sapek B., 1997. Metody analizy chemicznej gleb organicznych. Materiały Instruktażowe IMUZ, 115, 80 pp.

Schumann, M., Joosten, H., 2008. Global Peatland Restoration Manual. Institute of Botany and Landscape Ecology, Greifswald University, Germany, 68 pp.

Szuniewicz, J., Okruszko, H., Chrzanowski, S., 1998. Ruchy powierzchni i spłycanie się gleb torfowo-murszowych na torfowisku Wizna. Wiadomości IMUZ 19(3), 9-23.

Tomaszewska, K., Kołodziejczyk, K., 2010. Zróżnicowanie florystyczne i walory przyrodnicze nieużytkowanych łąk pobagiennych okolic Szczecina. Zeszyty Naukowe Uniwersytetu Przyrodniczego we Wrocławiu, Rolnictwo, XCVII, 578, 43-58.

Turbiak, J., Miatkowski, Z., 2010. Emisja CO2 z gleb pobagiennych w zależności od warunków wodnych siedlisk. Woda-Środowisko-Obszary Wiejskie 19(29), 201-210.

Urban, D., Tokarz, E., Sender, J., Smal, H., 2019. Chemical properties of small peatlands deposits (Eastern Polesie). International Agrophysics 33(2), 193-204. https://doi.org/10.31545/intagr/105521

von Post, L., 1922. Sveriges geologiska undersöknings torvinvenstering och några av dess hittills vaanna resultant. Svenska Mosskulturfören. Tidskr. 36, 1-27

Website 1: http://www.susza.iung.pulawy.pl/KBW

Website 2: https://dane.imgw.pl/data/dane_pomiarowo_obserwacyjne/

Wilson, J.M., 2008. Restoration of peatlands and greenhouse gas balances. In: Peatlands and Climate Change. Red. M. Strack. Jyväskylä. IPS, 182-210.

\section{Przeobrażenia gleb torfowo-murszowych w wyniku rolniczego użytkowania na obiekcie Supraśl Dolna (północno-wschodnia Polska)}

\author{
Słowa kluczowe \\ Zmeliorowane torfowiska \\ Poziom wody gruntowej \\ Właściwości fizyczno-wodne \\ Użytkowanie rolnicze \\ Degradacja torfowisk
}

\section{Streszczenie}

Torfowiska zajmują około 4\% powierzchni Polski i pełnią ważne funkcje środowiskowe i gospodarcze, w tym rolnicze. W ubiegłym wieku przeważający obszar torfowisk niskich został zmeliorowany poprzez ich odwodnienie. Odprowadzenie wody powodowało zmniejszenie retencyjności torfu i zainicjowało zmiany ich właściwości fizycznych i wodnych. W celu określenia tempa i zakresu zmian tych właściwości w latach 1987, 2007 oraz 2018 przeprowadzono badania na torfowisku niskim Supraśl Dolna (NE Polska) w dwóch prognostycznych kompleksach wilgotnościowo-glebowych: wilgotnym (PSMC-B) i posusznym (PSMC-C). Badania wykazały, że w kompleksie PSMC-B poziom wody gruntowej obniżał się maksymalnie do $100 \mathrm{~cm}$ poniżej poziomu terenu, natomiast w kompleksie PSMC-C woda gruntowa obniżała się nawet do $150 \mathrm{~cm}$ p.p.t. W kompleksie PSMC-B właściwości fizyczno-wodne w okresie badawczym zmieniły się w niewielkim zakresie (zmiany nieistotne statystycznie). W siedlisku PSMC-C nastąpiło obniżenie powierzchni torfowiska o $11 \mathrm{~cm}$, zwiększyła się gęstość objętościowa, uległy zmniejszeniu: porowatość ogólna i pełna pojemność wodna. Pogorszenie właściwości fizyczno-wodnych powoduje sukcesywną degradację i ewolucję badanych gleb organicznych w kierunku gleb mineralnych. W celu spowalniania, a nawet zatrzymania procesów degradacyjnych w płytkich i średniogłębokich glebach organicznych torfowo-murszowych zachodzi potrzeba zatrzymywania i regulowania odpływu wody za pomocą sprawnych urządzeń melioracyjnych, a także wykonywania technicznych prac renaturyzacyjnych. 